\title{
REGIONAL MILD HYPOTHERMIA IN THE PROTECTION OF THE ISCHEMIC BRAIN ${ }^{1}$
}

\author{
Mirto Nelso Prandini ${ }^{2}$ \\ Santino Nunes Lacanna ${ }^{3}$ \\ Paulo Roberto Valente ${ }^{4}$ \\ João Norberto Stavale ${ }^{5}$
}

\begin{abstract}
Prandini MN, Lacanna SN, Valente, Stavale JN. Regional mild hypothermia in the protection of the ischemic brain. Acta Cir Bras [serial online] 2002 Jul-Aug;17(4). Available from URL: http:// WWW.scielo.br/acb
\end{abstract}

\begin{abstract}
Objective: To demonstrate that mild hypothermia can be a protective element when an ischemic onset occurs in rabbit brains. Methods: A rabbit model of focal ischemia was used to test the protection provided by mild hypothermia regionally produced by means of the placement of ice bag on the scalp of a hemicranium which has had previously its bone removed. Twenty New Zealand White rabbits were divided into two groups as follows: (A) a control group where an ischemic lesion was produced by coagulation of the middle cerebral artery and (B) a brain protected group where mild hypothermia was provided during 80 to 100 minutes after the same ischemic lesion. The brains slices were stained with 2,3,5-Triphenyletrazolium (TTC). The sections were photographed with a digital camera and the infarct volume was measured through a computer program. Results: The average of infarct volume was $70.53 \mathrm{~mm}^{3}$ in the control group. In the protected group, the average of infarct volume was $41,30 \mathrm{~mm}^{3}$ only in five animals. Five animals of this group did not demonstrate macroscopically and microscopically infarct area. Conclusions: We concluded that mild hypothermia regionally produced may protect ischemic brains of rabbits.
\end{abstract}

KEY WORDS - Brain hypothermia. Neuroprotection. Brain ischemia. Brain infarct.

\section{INTRODUCTION}

Neurosurgeons and neurologists are often confronted with neurological disorders in which brain ischemia is present. Considerable research has focused upon ways to protect the brain from ischemic insults. Several drugs and different procedures have been attempted in order to minimize the brain lesions provoked by ischemia. They include hypothermia, mannitol, free radical scavengers, opiate receptor antagonists, metabolic suppressants, etc. ${ }^{(1,2,3)}$. Many others are still in laboratory tests ${ }^{(4,5)}$. Hypothermia has proved to reduce the ischemic damage in affected brains both in Humans and animals. Since $1956^{(6)}$ the neuroprotective effect of hypothermia has been the subject of many reports. Some different techniques to cooling the brain have been reported ${ }^{(7,8,9)}$. However, the adverse side effects of deep hypothermia have reduced the enthusiasm of its use ${ }^{(9,10,11)}$. The objective of the present study was to determine whether mild hypothermia, regionally produced, has neuroprotective benefits, after ischemic onset, by means of a new method of cooling the brain in a limited region, permitting the body temperature to remain unchanged.

1. Developed in the Laboratory of Microneuroanatomy of UNIFESP.

2. Adjunct Professor of Neurosurgery and Chairman of Laboratory of Microneuroanatomy UNIFESP.

3. Neurosurgeon. Head of Department of Neurosurgery Santa Casa de Santo Amaro.

4. Veterinarian. Post Graduate UNIFESP.

5. Adjunct Professor and Chairman of Department of Neuropathology UNIFESP. 


\section{METHODS}

Twenty New Zealand White rabbits weighting from $3100 \mathrm{~g}$ to $3750 \mathrm{~g}$ underwent surgical procedure for coagulation of the left middle cerebral artery.

The experiment was divided in two steps.

The first step consisted of a group of animals that did not receive the brain protection.

In the second group the animals received neuroprotection. The ischemic area of the brain was submitted to mild hypothermia of $29^{\circ} \mathrm{C}$ to $30,5^{\circ} \mathrm{C}$ over a period of 80 to 100 minutes. The hypothermia was achieved by the placement, over one hemicranium, of a rubber bag containing ice cubes, so that the temperature inside the ice bag was kept constant, near $0^{\circ} \mathrm{C}$ (varied from $0,5^{\circ} \mathrm{C}$ to $1,5^{\circ} \mathrm{C}$ ). (Digital Thermometer MET 9602 ELLAB A/S Denmark) The rectal temperature was measured and did not demonstrate any change during the experiment.

\section{Surgery}

The rabbits were anesthetized with intramuscular injection of Ketamine $10 \mathrm{mg} / \mathrm{Kg}+$ Aceprazolamine $1 \mathrm{mg} /$ $\mathrm{Kg}$ which was supplemented, by intravenous injection of Ketamine $10 \mathrm{mg} / \mathrm{Kg}+$ Aceprazolamine $1 \mathrm{mg} / \mathrm{Kg}$. The animals were intubated and general anesthesia with Halothane was maintained during the procedure. All the procedure was carried out under microscopic magnification. With the animal in the left lateral decubitus position, a scalp incision of approximately $2,5 \mathrm{~cm}$ in a $\mathrm{C}$ shape, between the left orbital rim and tragus was performed. The soft tissues were incised and the temporalis muscle was dissected from the cranium and retracted. The exposed skull bone was totally drilled off; the dura was exposed and incised in the region of the inferotemporal fossa. After the dural incision, the brain was gently retracted and the middle cerebral artery was followed down until its origin from the carotid artery. At this point the artery was coagulated. The scalp was closed with sutures. In some cases the coroniod process of the mandible had to be removed in order to permit to visualize the origin of the middle cerebral artery.

\section{Brain protection}

In the control group, the animals were maintained under general anesthesia for 80-100 minutes.

For the second group, ice bags were placed on the corresponding hemicranium for brain protection. The hypothermia $\left(29^{\circ} \mathrm{C}\right.$ to $\left.30,5^{\circ} \mathrm{C}\right)$ was maintained for 80 to 100 minutes, as described before.
After recovery from anesthesia, the endotracheal tube was removed and the animals were taken to specially designed cages where they received food and water. They were observed and all neurological deficits were recorded.

\section{Measurement of infarct volume}

Forty to forty five hours after recovery from surgery, the animals were killed. The brains were removed from the cranial vault, placed in ice-cold saline and taken to a refrigerator under a temperature of $-14^{\circ} \mathrm{C}$ for 10 minutes. The brains were placed in a specially designed brain cutter.

The slices measuring $2 \mathrm{~cm}$ were immersed in a solution of 2\% 2,3,5-triphenyltetrazolium (TTC) in $0,9 \%$ saline, incubated for 30 minutes in the dark, and then they were placed in a $10 \%$ formalin solution $(1,12,13,14,15)$.

After one week, with a digital camera, the sections were photographed. The pictures were taken to a computer program ( ADOBE PHOTOSHP EXE 5.0 and AUTO CAD R 14) where the infarct areas were measured and the infarct volume was calculated in $\mathrm{mm}^{3}$.

In the first group, the infarcted area measured, in $\mathrm{mm}^{3}$

\begin{tabular}{|r|}
\hline $1-114,2$ \\
$2-90,60$ \\
$3-68,84$ \\
$4-34,52$ \\
$5-66,40$ \\
$6-96,22$ \\
$7-47,18$ \\
$8-54,80$ \\
$9-60,42$ \\
$10-72,14$ \\
\hline
\end{tabular}

In the second group, five animals demonstrated areas of infarct measuring, in $\mathrm{mm}^{3}$ :
$11-32,62$
$12-0,00$
$13-18,20$
$14-0,00$
$15-0,00$
$16-28,96$
$17-0,00$
$18-0,00$
$19-88,24$
$20-38,48$ 
The brain slices of five animals (cases 12, 14, 15, 17 and 18) did not demonstrated any change of the TTC staining, so we presumed that there was not any macroscopically visible infarcted area. These five brains were taken to the Department of Neuro-Pathology, where the brain slices were embedded in paraffin and stained with hematoxylin and eosin. All the slices were examined by the senior Neuropathologist of the University, who could not find areas of infarct in the five brains examined, confirming our previous results.

\section{DISCUSSION}

Experimentally induced cerebral ischemia in laboratory animals has provided valuable information about the mechanisms of neuronal death ${ }^{(1,2)}$. The excessive release of endogenous excitatory amino acids, the effects on intra cellular calcium homeostasis in the cascade of neuronal death after ischemia are well established ${ }^{(3)}$. Numerous other mediators or modulators of ischemic damage were described, including nitric oxide, arachdonic acid and it's metabolites, neuropeptides and neurotransmitters ${ }^{(3,12,13,14)}$.

Rosomoff reported in $1956^{(6)}$ that deep hypothermia reduced ischemic damage after experimental occlusion of the middle cerebral artery in dogs. The animal's temperature was lowered to $23^{\circ} \mathrm{C}$ by means of an extracorporeal circuit. After that excellent report, the neuroprotective effect of hypothermia has been the subject of many subsequent reports.

However, deep hypothermia is not without adverse consequences: myocardial arrhythmia, hypotension, coagulopaty and other side effects were reported. Recent studies have demonstrated that cooling the brain by only a few degrees can prevent much of the neuronal damage that occurs after focal cerebral ischemia,. The adverse side effects are reduced if only the brain is cooled and only mild hypothermia is produced $(1,6,7,8,9,19,11,13)$

In 1992 Ohta $^{(10)}$ et al. introduced a method of selective cerebral hypothermic perfusion with cold Ringer's lactate solution by means of a specially designed extracorporeal system . In 1996 their method was modified by combining it with an ultrafiltration and rewarming circuit between the left jugular vein and inferior vena cava ${ }^{(11)}$. After temporary occlusion of both carotid artery and left vertebral artery, the neuro protective method demonstrated to be safe. Histological examination of the brain with 2,3,5-triphenyltetrazolin chloride demonstrated no evidence of ischemic lesion.

In our experimental model, to reduce the brain temperature to $30^{\circ} \mathrm{C}$, a rubber bag containing ice cubes was used. The temperature inside the bag varied from $0,5^{\circ} \mathrm{C}$ to $1,5^{\circ} \mathrm{C}$. The bag was positioned on the scalp over the area of hemicranium which had most of its bone removed. The cranial bone is a very important isolating element. Once the bone is removed, the placement of a bag under low temperature (near $0^{\circ} \mathrm{C}$ ) is able to provide a remarkable reduction of the brain temperature. This mild hypothermia, which is produced, if maintained during 80 to 100 minutes, demonstrated to be efficient to protect the ischemic brain. Although there is no time-limit to keep the rubber bag in position, the results of our experiments demonstrated that it was not necessary a longer period to achieve brain protection.

All the experimental animals, but one, that received the protection survived without neurological deficits. Most of the animals demonstrated a mild hemiparesis after recovery from general anesthesia that lasted for no more than 12 hours. All the animals that were not protected by hypothermia demonstrated contralateral hemiparesis, varying from mild to severe degrees, until they were sacrificed. All animals were sacrificed 45 to 50 hours after the surgical procedure. The caseN ${ }^{0}$ 19 of the group of neuroprotection, had an outcome as if he did not had received neuroprotection. We could not find any explanation for this. The exact mechanism whereby hypothermia exerts its effects is not entirely understood $(1,3,4,5,12,13)$. Lowering the temperature of neuronal tissue is known to be associated with a reduction in metabolic rate. Activated polymorphonuclear leukocytes seem to be directly involved in potentiating ischemic brain injury ${ }^{(12)}$. The leukocyte adhesion process may be reduced by hypothermia. Indications of the involvement in ischemic damage of cytokines, classically associated with the immune system and inflammatory responses, have been recently demonstrated ${ }^{(4)}$ Several factors related to inflammatory process, present in brain ischemia, can be mitigated by the reduction of brain temperature. Mild hypothermia, probably, does not interfere with the effect of other drugs administrated in the treatment of brain ischemia, therefore association with other new drugs can be very helpful. Although the technique requires the removal of part of the cranial vault, in most of neurosurgical procedures, the cranial bone must be removed. The removal of part of the cranial vault is a very simple procedure, its risks are very low and, in some occasions, the procedure can be done under local anesthesia. Because this technique is unique we could not match our results with other publications.

\section{Conclusions}

In summary, our experiments demonstrated that the brain can be cooled selectively, without cooling the whole body, by the use of this method. The method may be useful to protect the brain in any case in which 
a severe brain injury had occurred and brain protection could be useful, mainly in cases when the adverse side effects of cooling the whole body should be avoided.

\section{REFERENCES}

1. Ogilvy CS, Chu D, Kaplan S. Mild hypothermia, hipertension and mannitol are protective against infarction during experimental intracranial temporary vessel occlusion. Neurosurgery 1996;38:1202-09.

2. Amar PA, Levy ML. Pathogenesis and pharmacological strategies for mitigating secondary damage in acute spinal cord injury . Neurosurgery 1999;44:1027-39.

3. Tymianski M, Tator $\mathbf{C H}$. Normal and abnormal calcium homeostasis in neurons : a basis for the pathophysiology of traumatic and ischemic central nervous system injury. Neurosurgery 1996;38: 1176-97.

4. Huh SK, Lipton JM, Batjer HH. The protective effects of a melanocyte stimulating hormone on canine brain stem ischemia. Neurosurgery 1997;40:132-7

5. Miles NA, Majda BT, Meloni BP, Knuckey NW. Postischemic intravenous administration of magnesium sulfate inhibits hippocampal CA1 neuronal death after transient global ischemia in rats. Neurosurgery 2001;49:1443-51.

6. Rosomoff HL. Hypothermia and cerebral vascular lesions: 1 Experimental interruption of the middle cerebral artery during hypothermia. J Neurosurg 1956;13:244-55.

7. Guegan Y, Scarabin JM, LeGilcher C, Guillon I. Extracorporeal circulation with deep hypothermia and circulatory arrest in the treatment of intracranial aneurism. Surg Neurol 1985;24:441-8

8. Chyatte D, Elefteriades J, Kin B. Profound Hypothermia and circulatory arrest for aneurysm surgery: Case report. J Neurosurg.1989;70: 489-91.

9. Silveberg GD, Reitz BA, Ream AK, Taylor C, Enzman DR. Operative treatment of a giant cerebral artery aneurysm with hypothermia and circulatory arrest: report of a case. Neurosurgery 1980;6:301-5.

10. OhtaT, Sakaguchi I, Baldwin M , Liu W, Yasuda A. Selective cooling of brain using profound hemodilution in dogs. Neurosurgery 1992;31:1049-55

11. Ohta T, Kuroiwa T, Sakaguchi I, Sakai N, Moriwaki K. Selective hypotermic perfusion of canine brain. Neurosurgery 1996; 38:1211-5

12. Yanaka K, Camarata PJ, Spellman SR, McCarty JB, Furcht L,Low WC. Antagonism of leukocyte adherence by synthetic fibronectin peptide $\mathrm{V}$ in a rat model of transient focal cerebral ischemia. Neurosurgery 1997;40:537-64.

13. Markarian GZ, Lee JH, Stein DJ, Hong SC. Mild Hypothermia: Therapeutic window after experimental cerebral ischemia. Neurosurgery 1996;38:542-51.

14. Connoly ES, Winfree CJ, Solomon RA, Pinsky DJ. Procedural and strain-related variables significantly affect outcome in a murine model of focal cerebral ischemia. Neurosurgery 1996;38:523-32

15. Bederson JB, Pitts LH, Germano SM, Nishimura MC, Davis RI, Bartkowski HM. Evaluation of 2,3,5-triphenyltetrazolium chloride as a stain for detection and quantification of experimental cerebral infarction in rats. Stroke 1986;17:1304-08.

Prandini MN, Lacanna SN, Valente P, Satavale JN. A hipotermia regional moderada na proteção do encéfalo isquêmico. Acta Cir Bras [serial online] 2002 Jul-Ago;17(4). Disponível em URL: http:// www.scielo.br/acb.

RESUMO Objetivo: Demonstrar a proteção que a hipotermia moderada pode fornecer em casos de isquemia em encéfalos de coelhos. Métodos: Foi utilizado um modelo de isquemia focal em coelhos, para avaliar a proteção fornecida por meio de hipotermia moderada, produzida através da colocação de pedras de gelo contidas no interior de um pequeno saco plástico, em contato com o couro cabeludo de um hemicrânio onde a tábua óssea foi previamente removida. Vinte coelhos da raça Nova Zelândia Branca, pesando de 3,100 Kg a 3,750 Kg foram divididos em dois grupos: (A) um grupo controle onde foi produzida uma lesão isquêmica por meio da coagulação da artéria cerebral média e (B) um grupo submetido a neuroproteção por hipotermia moderada regional durante 80 a 100 minutos após a produção da mesma lesão isquêmica. As secções de encéfalos foram coradas com 2,3,5-Tryphenyltetrazolium (TTC). As lâminas foram fotografadas com câmara digital e o volume de infarto foi calculado através de um programa de computador. Resultados: $\mathrm{O}$ volume médio de infarto foi de $70,53 \mathrm{~mm}^{3}$ no grupo controle, enquanto que o grupo com neuroproteção apresentou média de $41,30 \mathrm{~mm}^{3}$ em 5 animais. Cinco animais deste grupo não demonstraram macroscópica e microscopicamente áreas de infarto. Conclusões: Concluímos que a hipotermia moderada, localmente aplicada, pode proteger encéfalos isquêmicos de coelhos.

DESCRITORES - Hipotermia encefálica. Neuroproteção. Isquemia cerebral. Infarto cerebral.

\section{Address for correspondence:}

Mirto N. Prandini

Rua Dos Crisântemos 117

04049-020 São Paulo - SP

Phone: (11) 275-4602 - Fax: (11) 5071-3774
Conflito de interesse: nenhum Fonte de financiamento: FAPESP

Data do recebimento: 28/04/2002

Data da revisão: 11/05/2002

Data da aprovação: 17/06/2002 